\title{
Oxidant-antioxidant imbalance in the experimental interstitial lung disease induced in sheep by visna-maedi virus
}

\author{
V. Cottin, I. Court-Fortune, J. Crevon, J-F. Mornex
}

Oxidant-antioxidant imbalance in the experimental interstitial lung disease induced in sheep by visna-maedi virus. V. Cottin, I. Court-Fortune, J. Crevon, J-F. Mornex. (CERS Journals Ltd 1996.

ABSTRACT: Infection of sheep by visna-maedi virus causes an interstitial pneumonitis similar to that associated with human immunodeficiency virus type-1 (HIV1). Visna-maedi virus infection of alveolar macrophages leads to their activation.

In this study we determined whether an imbalance in oxidant-antioxidant activity may be involved in the pathogenesis of the disease.

We investigated the spontaneous and phorbol myristate acetate (PMA)-induced release of hydrogen peroxide $\left(\mathrm{H}_{2} \mathrm{O}_{2}\right)$, and the activities of superoxide dismutase and glutathione peroxidase in alveolar macrophages from lambs experimentally-infected with visna-maedi virus, and in ovine alveolar macrophages infected in vitro.

Alveolar macrophages from lambs experimentally-infected in vivo exhibited normal spontaneous $\mathrm{H}_{2} \mathrm{O}_{2}$ release and had superoxide dismutase and glutathione peroxidase activities similar to those from control animals. In contrast, after in vitro stimulation with PMA the $\mathrm{H}_{2} \mathrm{O}_{2}$ production by macrophages from experimentallyinfected lambs was significantly increased. Similarly, spontaneous and PMA-induced $\mathrm{H}_{2} \mathrm{O}_{2}$ production by in vitro infected macrophages was significantly increased as compared to controls.

In conclusion, the increased capacity of alveolar macrophages infected with the human immunodeficiency virus type-1-related visna-maedi virus to release hydrogen peroxide on stimulation suggests an oxidant-antioxidant imbalance, which may contribute to the pathogenesis of the observed chronic interstitial pneumonitis. Eur Respir J., 1996, 9, 1983-1988.

\begin{abstract}
Laboratoire d'Immunologie et de Biologie Pulmonaire, INSERM CJF 93-08, and Service de Pneumologie, Hôpital Louis Pradel, and Faculté de médecine Grange Blanche, Université Claude Bernard, and Laboratoire de Recherche sur les Lentivirus chez les Petits Ruminants, INRA and Ecole Vétérinaire, Lyon, France.
\end{abstract}

Correspondence: J-F. Mornex

Hôpital Louis Pradel

BP Lyon Monchat

69394 Lyon Cedex 03

France

Keywords: Hydrogen peroxide interstitial pneumonitis

lentiviruses

ovine progressive pneumonia

oxidant

superoxide dismutase

Received: July 121995

Accepted after revision June 151996

Supported in part by grants from Agence Nationale de Recherche sur le SIDA.
Visna-maedi virus is a lentivirus related to human immunodeficiency virus type-1 (HIV-1). Spontaneous infection of sheep by visna-maedi virus is responsible for multivisceral degenerative and chronic inflammatory lesions, including a progressive interstitial pneumonitis (known as maedi) [1, 2], which shows similarities with HIV-1associated interstitial pneumonitis [3]. Maedi is characterized by peribronchiolar and perivascular proliferative lymphoid follicles, smooth muscle hyperplasia, diffuse intraluminal and mural alveolitis, and fibrosis [4]. The process of alveolitis involves macrophages, lymphocytes and neutrophils [5]. Similar but milder pathological abnormalities can be reproduced by experimental intratracheal inoculation of newborn lambs with visna-maedi virus preparations $[6,7]$. A lymphocytic alveolitis is also present in this experimentally-induced lung disease [8].

Visna-maedi virus infection of alveolar macrophages leads to their activation and induces a high level of expression of major histocompatibility complex (MHC) class II antigens, and the release of fibronectin, neutrophil chemotactic activity [5], and procoagulant activity [9]. Activated alveolar macrophages have been shown to release reactive oxygen species (ROS), including hydrogen peroxide $\left(\mathrm{H}_{2} \mathrm{O}_{2}\right)$, superoxide $\left(\mathrm{O}_{2}{ }^{-}\right)$, and nitric oxide $(\mathrm{NO})$ $[10,11]$. The toxicity of ROS are normally balanced by several intracellular and extracellular antioxidant defence systems. The major pulmonary antioxidant enzyme systems are superoxide dismutase, catalase, and the enzymes of the glutathione redox cycle, such as glutathione peroxidase and glutathione reductase [12]. An oxidant-antioxidant imbalance, through an increase in oxidant stress or a compromise in antioxidant resources, has been implicated in various lung conditions, including the adult respiratory distress syndrome, hyperoxic lung injury, cigarette-smoke effects, exposure to air pollutants (ozone), xenobiotic-induced lung injury, ischaemia-reperfusion lung injury, idiopathic pulmonary fibrosis, and HIV-1associated lung disease $[12,13]$. We hypothesized that an imbalance in oxidant-antioxidant activity may be involved in the pathogenesis of the interstitial lung disease induced in sheep by visna-maedi virus. We have investigated the release of $\mathrm{H}_{2} \mathrm{O}_{2}$ and the superoxide dismutase and glutathione peroxidase activities of alveolar macrophages from lambs experimentally-infected with visna-maedi virus, and of in vitro infected ovine alveolar macrophages. 


\section{Methods}

\section{Production of visna-maedi virus stock preparations}

Virus stocks were prepared from field isolates of visnamaedi virus checked by reverse transcriptase activity, electron microscopy and/or positive immunofluorescence with a polyclonal sheep serum as described previously [8]. Each visna-maedi virus stock was made by mixing three different field isolates; one from blood monocytes and one from alveolar macrophages of animals with natural maedi and the third from a lung explant of an experimentally-infected animal. Each was obtained by productive viral replication at low passage $(n=3)$ in ovine skin fibroblasts (IDO5 strain, kindly provided by J. Laplace, Rhône-Merieux, Lyon, France). The prototype visna-maedi strain K1514 (kindly provided by G. Chapuis, Rhône-Merieux) was prepared by productive viral replication in IDO5 fibroblasts. Culture supernatants were collected and stored frozen until use, the stock preparations titrated between $10^{5.3}$ and $10^{6.5} 50 \%$ tissue culture infective dose $\left(\mathrm{TCID}_{50}\right) \cdot \mathrm{mL}^{-1}$. The absence of endotoxin contamination of the virus preparations was checked by the Limulus amoebocyte lysate assay (QCL 1000; BioWhittaker, USA).

\section{Inoculation of lambs}

Lambs (Lacaune strain) were separated from the ewes at birth, before suckling, and inoculated transtracheally as reported previously [7]. Animals receiving virus $(n=12)$ were inoculated with $2 \mathrm{~mL}$ of purified virus, whereas controls $(n=5)$ received the same volume of saline. The different groups were stalled separately to prevent horizontal transmission of the virus and were maintained by artificial feeding. Care was taken to maintain and use the lambs in agreement with the French regulation on animal experimentation (authorization number 02623). All animals were slaughtered at 3 months by intravenous infusion of xylazine and exsanguination. Lungs from lambs and from adult sheep were excised immediately after death. For in vitro infection, lungs from a healthy adult sheep were obtained from the slaughterhouse.

\section{Histological analysis}

Fragments for tissue studies were taken from the dorsal part of the right posterior lobe of lungs. Histological examination was performed as described previously [4].

\section{Preparation of alveolar cell suspensions}

The alveolar cells from lambs and adult sheep were obtained by bronchoalveolar lavage (BAL) and analysed as described previously [5]. Cell viability, monitored at this step by counting the percentage of cells that excluded trypan blue, was regularly over $85 \%$. Cell counts per microlitre of recovered BAL fluid were established with a haemocytometer. The cells were washed twice with phosphate buffered saline (Gibco BRL) and suspended at a concentration of $2 \times 10^{6}$ cells $\cdot \mathrm{mL}^{-1}$ in Dulbecco-modified Eagle's minimum essential medium (DMEM) (Gibco BRL) containing $8 \%$ foetal calf serum (FCS).

\section{Virus isolation}

Cells obtained by BAL were co-cultured with IDO5 cells, as described previously [5], to detect the presence of virus. Virus infection was indicated by the appearance of syncytia (>8 nuclei $\cdot$ cell $^{-1}$ ) after 10-30 days of culture. The syncytia were confirmed by fixation and staining of the fibroblasts with May-Grünwald-Giemsa. Cultures with no syncytia after at least 60 days of co-culture and/or 10 passages were considered negative. In addition, supernatants of co-cultures were analysed for reverse transcriptase activity as described previously [14], except that $10 \mathrm{mM}$ magnesium acetate was used instead of 1 $\mathrm{mM}$ manganese acetate.

\section{Assay for hydrogen peroxide production}

Production of $\mathrm{H}_{2} \mathrm{O}_{2}$ by alveolar macrophages was measured using the method described by PICK and KEISARI [15], based on the horseradish peroxidase-dependent oxidation of phenol red by $\mathrm{H}_{2} \mathrm{O}_{2}$, which results in the formation of a compound absorbing at $610 \mathrm{~nm}$. Alveolar macrophages were isolated by differential adherence. The cells, suspended in DMEM containing $8 \%$ FCS, were seeded into 96-well tissue culture plates with flat bottoms (Microtest III ${ }^{\mathrm{TM}}$; Falcon 3072, Becton Dickinson) at $0.3 \times 10^{6}$ cells $\cdot$ well $^{-1}$. Incubation for $2 \mathrm{~h}$ at $37^{\circ} \mathrm{C}$ in $90 \%$ air $10 \% \mathrm{CO}_{2}$, allowed the adherence of macrophages to the plates. Nonadherent cells were then removed by rinsing with $100 \mu \mathrm{L}$ Hanks's balanced salt solution (HBSS), (Gibco BRL) without phenol red, prewarmed to $37^{\circ} \mathrm{C}$. Adherent cells were covered with phenol red assay solution, containing $140 \mathrm{mM} \mathrm{NaCl}, 10 \mathrm{mM}$ potassium phosphate buffer, $\mathrm{pH} 7.0,5.5 \mathrm{mM}$ dextrose, 0.56 $\mathrm{mM}$ phenol red (Sigma, Nanterre, France), and $19 \mathrm{U} \cdot \mathrm{mL}^{-1}$ of horseradish peroxidase (Sigma). Alveolar macrophages were stimulated with three different concentrations $(0.01$, 0.1 , and $1 \mu \mathrm{g} \cdot \mathrm{mL}^{-1}$ ) of phorbol myristate acetate (PMA), and the plates were incubated for $1 \mathrm{~h}$ at $37^{\circ} \mathrm{C}$.

At the completion of incubation, the supernatants were made alkaline by adding $\mathrm{NaOH} 1 \mathrm{~N}, 10 \mu \mathrm{L} \cdot$ well $^{-1}$. The samples were read at $610 \mathrm{~nm}$ (Titertek Multiskan, Flow, France) against a blank of phenol red assay solution to which $10 \mu \mathrm{L}$ of $\mathrm{NaOH} 1 \mathrm{~N}$ had been added. Standard curves were made using the same preparation of phenol red solution, with $1-100 \mathrm{nM} \mathrm{H} \mathrm{O}_{2}$ solutions. The standards were treated in the same manner as the culture supernatants. The amount of $\mathrm{H}_{2} \mathrm{O}_{2}$ produced was calculated from the standard curve. In each experiment, three wells of adherent macrophages were used for determining the amount of cell protein. The monolayers were scraped into $\mathrm{NaOH} 1 \mathrm{~N}$, and protein concentration determined according to the method of LowRY et al. [16]. The results were expressed as nanomoles of $\mathrm{H}_{2} \mathrm{O}_{2}$ generated per milligram of cell protein.

\section{Superoxide dismutase activity}

The role of superoxide dismutase is to accelerate the dismutation of superoxide radicals $\left(\mathrm{O}_{2}{ }^{-}\right)$to hydrogen peroxide and molecular oxygen. The assay (Ransod superoxide dismutase ${ }^{\mathrm{TM}}$; Randox, Crumlim, UK) employed xanthine and xanthine oxidase to generate superoxide 
radicals which reacted with 2-(4-iodophenyl)-3-(4-nitrophenol)-5-phenyl tetrazolium chloride (INT) to form a red formazan dye. Superoxide dismutase activity was then measured by the degree of inhibition of this reaction. Briefly, alveolar cells suspended in DMEM containing $8 \%$ FCS were seeded into 96-well tissue culture plates as described above, and incubated for $24 \mathrm{~h}$ at $37^{\circ} \mathrm{C}$ in $90 \%$ air $/ 10 \% \mathrm{CO}_{2}$. After removing nonadherent cells by rinsing with HBSS adherent cells were lysed with triton $0.1 \%$. Assays were routinely performed at $37^{\circ} \mathrm{C}$ in 50 $\mathrm{mmol}^{-1}$ 3-cyclohexylamino-1-propanesulphonic acid, $\mathrm{pH}$ 10.2, containing $0.94 \mathrm{mmol}^{-1}$ ethylenediamine tetra-acetic acid (EDTA), according to the recommendations of the manufacturer. The absorbance was measured at $505 \mathrm{~nm}$ (Multiskan) against a blank consisting of xanthine, INT, and phosphate buffer. A calibration curve was obtained using standards. The results were expressed as units of superoxide dismutase activity per milligram cell protein.

\section{Glutathione peroxidase activity}

Glutathione peroxidase activity catalyses the oxidation of glutathione by cumene hydroperoxide; in the presence of glutathione reductase and nicotinamide adenine dinucleotide phosphate reduced form (NADPH), the oxidized glutathione is immediately converted to the reduced form with a concomitant oxidation of NADPH to nicotinamide adenine dinucleotide phosphate $\left(\mathrm{NADP}^{+}\right)$. Glutathione peroxidase was measured by the method described by Paglia and Valentine [17], in which the decrease in absorbance at $340 \mathrm{~nm}$ is measured. Alveolar macrophages were selected by $24 \mathrm{~h}$ adherence and lysed with triton $0.1 \%$, as described above. Assays were performed according to the manufacturer's recommendations (Ransel glutathione peroxidase ${ }^{\mathrm{TM}}$; Randox).

\section{In vitro virus infection of macrophages}

Uninfected macrophages, obtained as described above from healthy adult sheep lungs, were seeded into 96-well tissue culture plates (Microtest III TM; Falcon 3072; Becton Dickinson), $0.3 \times 10^{6}$ cells $^{\cdot}$ well $^{-1}$ in $150 \mu \mathrm{L}$ of antibioticsupplemented DMEM. After $24 \mathrm{~h}$ adherence, cultures were inoculated with $50 \mu \mathrm{L}$ of the $\mathrm{K} 1514$ stock $\left(10^{8}\right.$ $\left.\mathrm{TCID}_{50} \cdot \mathrm{mL}^{-1}\right)$ or with $50 \mu \mathrm{L}$ of the heat-inactivated $\left(56^{\circ} \mathrm{C}\right.$ for $30 \mathrm{~min}$ ) K1514 stock. Controls were mock-infected with medium alone, or with the supernatant of uninfected fibroblast cultures. The flasks were incubated overnight at $37^{\circ} \mathrm{C}$ in $95 \%$ air $/ 5 \% \mathrm{CO}_{2}$. The cells were then stimulated with $0.01 \mu \mathrm{g} \cdot \mathrm{mL}^{-1}$ of PMA, and the plates were incubated for $1 \mathrm{~h}$ in the same conditions before harvesting the cells for measurement of $\mathrm{H}_{2} \mathrm{O}_{2}$ production.

\section{Statistical analysis}

The results shown are the mean of duplicate determination for each sample. Results are expressed as arithmetic mean \pm SEM. The data were analysed by the nonparametric Mann-Whitney U-test using the Statwork ${ }^{\mathrm{TM}}$ package (DataMetrics, Philadelphia, PA, USA) run on a Macintosh ${ }^{\mathrm{TM}}$ computer. Differences were considered significant when $\mathrm{p}$-values were below 0.05 .

\section{Results}

\section{Experimental infection and induction of lesions}

Histological examination. Lungs from virus-inoculated lambs were normal in two out of 12 cases. Multifocal peribronchovascular lymphoid nodules were present in eight cases, and peribronchovascular and perialveolar lymphocytic infiltration in 10 cases out of 12 ; these were classified as minor lesions, according to criteria described previously [4]. Histological examination of lungs from the adult sheep and from three out of five control lambs showed a slight thickening of the alveolar septa by oedema and/or minor lymphocytic infiltration; lungs were histologically normal in the two remaining control lambs.

Lentivirus detection. No cytopathic effect was observed when fibroblasts were cultured alone. In contrast, positive viral isolation, as demonstrated by cytopathic effect in co-culture with BAL cells, was obtained in 11 out of 12 experimentally-infected lambs. Co-cultures from 10 out of 12 experimentally-infected lambs exhibited significant reverse transcriptase activity. Thus, viral infection was demonstrated in 10 out of 12 experimentallyinfected lambs. A cytopathic effect in co-culture with BAL cells was observed in three out of five control lambs, and was not present in one control lamb; co-cultures were contaminated by fungi in the remaining control lamb. None of the five control lambs exhibited significant reverse transcriptase activity. Thus, the positive cytopathic effect in three control lambs was considered as a false positive.

BAL fluid cell counts. The total cell count was significantly higher in experimentally virus-inoculated lambs than in control lambs (table 1), demonstrating a process of alveolitis in infected animals, as described previously [8]. The alveolitis was characterized by a significant increase both in macrophage and lymphocyte counts (table

$1)$. There was no increase in the number of neutrophils.

\section{Hydrogen peroxide production by alveolar macrophages}

The spontaneous $\mathrm{H}_{2} \mathrm{O}_{2}$ production by the bronchoalveolar macrophages was not increased in experimentallyinfected lambs $\left(46.2 \pm 16.3 \mathrm{nmol} \cdot \mathrm{mg}^{-1}\right.$ cell protein), as compared with values from control animals $(84 \pm 44.9$ $\mathrm{nmol} \cdot \mathrm{mg}^{-1}$ cell protein; $\mathrm{p}=0.22$ ) (fig. 1 ). In contrast, after

Table 1. - Bronchoalveolar lavage fluid cell counts in experimentally-infected lambs and controls

\begin{tabular}{lccccc}
\hline & \multicolumn{2}{c}{$\begin{array}{c}\text { Infected lambs } \\
(\mathrm{n}=12)\end{array}$} & & \multicolumn{2}{c}{$\begin{array}{c}\text { Controls } \\
(\mathrm{n}=5)\end{array}$} \\
\cline { 2 - 3 } \cline { 5 - 6 } & cells $\mu \mathrm{L}^{-1}$ & $\%$ & & cells $\cdot \mu \mathrm{L}^{-1}$ & $\%$ \\
\hline Total cells & $668 \pm 50^{* *}$ & & & $333 \pm 50$ & \\
Macrophages & $464 \pm 36^{* *}$ & 70 & & $263 \pm 44$ & 79 \\
Lymphocytes & $196 \pm 25^{* *}$ & 29 & & $59 \pm 11$ & 18 \\
Neutrophils & $9 \pm 2$ & 1.3 & & $10 \pm 3$ & 3.0 \\
\hline
\end{tabular}

Values are presented as mean \pm SEM and as percentage of total cells. **: $\mathrm{p} \leq 0.01$, significant differences between the two groups. 


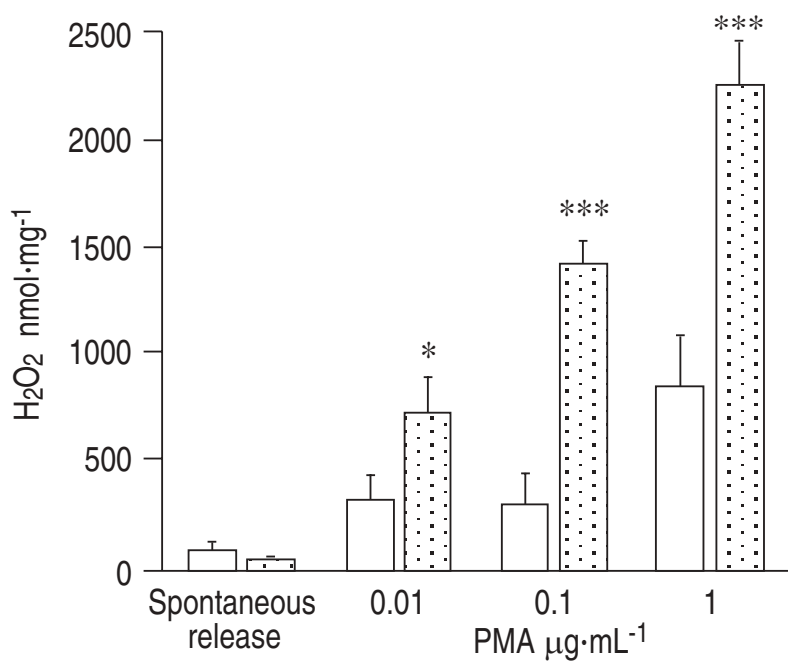

Fig. 1. - Spontaneous and phorbol myristate acetate (PMA)-induced release of hydrogen peroxide $\left(\mathrm{H}_{2} \mathrm{O}_{2}\right)$ by alveolar macrophages from lambs experimentally-infected with virus $(n=12)$ and control lambs $(\mathrm{n}=5) . \quad *: \mathrm{p}<0.05 ; \quad * * *: \mathrm{p}=0.001$, significant difference between groups. : uninfected; 1 : infected:

in vitro stimulation with $0.01,0.1$ or $1 \mu \mathrm{g} \cdot \mathrm{mL}^{-1}$ of PMA the $\mathrm{H}_{2} \mathrm{O}_{2}$ production by macrophages was significantly increased in experimentally-infected lambs as compared with controls: $729 \pm 164$ vs $326 \pm 116 \mathrm{nmol} \cdot \mathrm{mg}^{-1}$ cell protein, $(\mathrm{p}<0.05) ; 1,412 \pm 119$ vs $308 \pm 146 \mathrm{nmol} \cdot \mathrm{mg}^{-1}(\mathrm{p}=0.001)$; and $2,247 \pm 214$ vs $850 \pm 238 \mathrm{nmol} \cdot \mathrm{mg}^{-1}(\mathrm{p}=0.001)$, respectively (fig. 1). The spontaneous and PMA-induced $\mathrm{H}_{2} \mathrm{O}_{2}$ production by macrophages was not increased in control lambs with a positive cytopathic effect in co-culture as compared with control lambs without viral cytopathic effect (not shown).

Results of $\mathrm{H}_{2} \mathrm{O}_{2}$ production after in vitro infection of alveolar macrophages from healthy adult sheep are shown on figure 2. Spontaneous and PMA-induced $\mathrm{H}_{2} \mathrm{O}_{2}$ production were increased in experimentally-infected macrophages (spontaneous: $1,209 \mathrm{nmol} \cdot \mathrm{mg}^{-1}$ cell protein; PMA $0.01 \mu \mathrm{g} \cdot \mathrm{mL}^{-1}: 2,392 \mathrm{nmol} \cdot \mathrm{mg}^{-1}$ cell protein) as compared

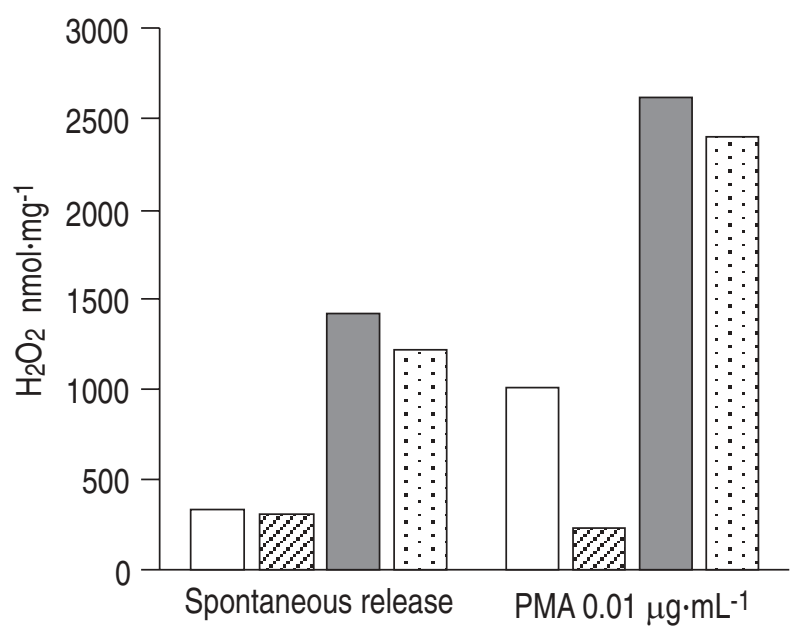

Fig. 2. Spontaneous and phorbol myristate acetate (PMA)-induced release of hydrogen peroxide $\left(\mathrm{H}_{2} \mathrm{O}_{2}\right)$ by in vitro infected alveolar macrophages and controls. Results were obtained from duplicate experiments. : control (medium); : supernatant of uninfected fibroblast culture; , : heat-inactivated virus; $\bar{i}$ : active virus. with control (spontaneous: $320 \mathrm{nmol} \cdot \mathrm{mg}^{-1}$ cell protein; PMA $0.01 \mu \mathrm{g} \cdot \mathrm{mL}^{-1}: 1,002 \mathrm{nmol} \cdot \mathrm{mg}^{-1}$ cell protein; $\mathrm{p}=0.03$ for both spontaneous and PMA, infected $v s$ uninfected) (fig. 2). $\mathrm{H}_{2} \mathrm{O}_{2}$ production was also progressively increased when infected macrophages were stimulated with 0.1 or $1 \mu \mathrm{g} \cdot \mathrm{mL}^{-1}$ of PMA (data not shown). Spontaneous and PMA-induced $\mathrm{H}_{2} \mathrm{O}_{2}$ production was not altered by heat inactivation of the virus preparation (spontaneous: $1,416 \mathrm{nmol} \cdot \mathrm{mg}^{-1}$ cell protein; PMA $0.01 \mu \mathrm{g} \cdot \mathrm{mL}^{-1}: 2,610$ nmol $\cdot \mathrm{mg}^{-1}$ cell protein) (fig. 2). $\mathrm{H}_{2} \mathrm{O}_{2}$ production was not increased when macrophages were treated with supernatants from uninfected fibroblast cultures (spontaneous: $304 \mathrm{nmol} \cdot \mathrm{mg}^{-1}$ cell protein; PMA $0.01 \mu \mathrm{g} \cdot \mathrm{mL}^{-1}: 237$ $\mathrm{nmol} \cdot \mathrm{mg}^{-1}$ cell protein) as compared with medium alone (fig. 2).

\section{Superoxide dismutase and glutathione peroxidase activities}

Glutathione peroxidase activity was not different in experimentally-infected lambs $\left(0.09 \pm 0.01 \mathrm{U} \cdot \mathrm{mg}^{-1}\right.$ cell protein; $\mathrm{n}=12)$ and in control lambs $\left(0.09 \pm 0.01 \mathrm{U} \cdot \mathrm{mg}^{-1}\right.$ cell protein; $n=5)(p=0.38)$. Similarly, no significant difference was found in superoxide dismutase activity between infected $(n=12)$ and uninfected $(n=5)$ lambs $\left(0.51 \pm 0.1\right.$ versus $0.43 \pm 0.1 \mathrm{U} \cdot \mathrm{mg}^{-1}$ cell protein, respectively) $(\mathrm{p}=0.24)$.

\section{Discussion}

In this study, it was shown that alveolar macrophages from lambs experimentally-infected in vivo exhibit a normal spontaneous $\mathrm{H}_{2} \mathrm{O}_{2}$ release and superoxide dismutase and glutathione peroxidase activities as compared with macrophages from control animals. In contrast, after in vitro stimulation with PMA the $\mathrm{H}_{2} \mathrm{O}_{2}$ production by macrophages is significantly increased in experimentallyinfected lambs as compared with controls, suggesting that the virus may have "primed" these cells to produce reactive oxygen species. Finally, the spontaneous and PMA-induced $\mathrm{H}_{2} \mathrm{O}_{2}$ production are increased in in vitro infected macrophages as compared with controls.

The effect of HIV-1 on the release of ROS by mononuclear phagocytes in vivo remains controversial [18-26]. However, in vitro experiments have demonstrated that HIV-1 infection of macrophages did not decrease their ability to generate $\mathrm{H}_{2} \mathrm{O}_{2}$ when treated with PMA or zymosan [27]. Similarly, an increase in lipid peroxidation has been reported $[28,29]$. On the other hand, reduced concentrations of acid-soluble thiol (cysteine and reduced glutathione) have been reported in cell lysates of peripheral blood mononuclear cells [30], in venous plasma and in lung epithelial lining fluid [31] of symptomfree HIV-1-infected individuals, and it is likely that the glutathione deficiency contributes to the pathogenesis of HIV-1-related lesions [32].

The present study supports the concept of the activation of alveolar macrophages during visna-maedi virus infection. We have previously shown that visna-maedi virus infection of alveolar macrophages leads to the expression of MHC class II antigens on most of these cells [5]. Infected alveolar macrophages also release fibronectin, neutrophil chemotactic activity [5], procoagulant activity [9], and express tissue factor [9] and 
interleukin(IL)-8 messenger ribonuclear acid (mRNA) [33]. Together with these findings, the present demonstration of an increased oxidant release confirms that visnamaedi virus-infected alveolar macrophages are activated.

The molecular mechanisms by which the high level of ROS, particularly $\mathrm{H}_{2} \mathrm{O}_{2}$ release, contribute to the pathogenesis of lentivirus-associated pulmonary lesions remain poorly understood. ROS have been shown to increase the production of cytokines, such as IL-1 or IL-8 [34, 35]. Recently, in vitro studies have demonstrated that low concentrations of $\mathrm{H}_{2} \mathrm{O}_{2}$ activate intracellular transcription nuclear factor kappa-B $(\mathrm{NF}-\kappa \mathrm{B})$ post-translationally, and that the activation of $N F-\kappa B$ by $\mathrm{H}_{2} \mathrm{O}_{2}$ is prevented by the antioxidant $\mathrm{N}$-acetyl-L-cysteine [36]. Similarly, the transactivator, Tax, from human T-cell leukaemia virus type-1 (HTLV-1) enhances the produc-

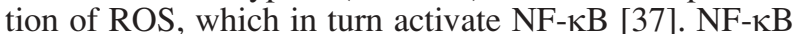
activates the transcription of genes involved in immune responses, leading to the production of several cytokines [38]. In particular, NF- $\kappa \mathrm{B}$ activates transcription of the IL-8 gene [39, 40]. The release of ROS and subsequent activation of NF- $\mathrm{KB}$ may explain, at least in part, the induction of IL-8 gene expression observed in alveolar macrophages from visna-maedi virus-infected animals [33]. The release of proinflammatory cytokines, such as IL-8, may in turn contribute to the alveolar recruitment of inflammatory cells and then to the pathogenesis of the disease. Moreover, ROS have the potential to increase HIV-1 gene expression [41, 42] via $\mathrm{NF}-\kappa \mathrm{B}-$ mediated transcription pathways [36], and they probably play a role in regulating HIV-1 replication in vitro $[36,43,44]$. The release of ROS during lentiviral infection may then lead to a self-amplifying loop of viral expression and replication. However, the role of ROS in regulating the visnamaedi replication in vitro, and to a greater extent in vivo, remains speculative.

Nevertheless, the high level of hydrogen peroxide release during visna-maedi infection, coupled with the nonstimulated level of antioxidant, are likely to contribute to an oxidant-antioxidant imbalance that can contribute to the pathogenesis of the chronic interstitial pneumonitis induced in sheep by the human immunodeficiency virus type-1 related visna-maedi virus.

Acknowledgements: The authors thank J. Patet for initiation of the study, and T. Greenland for reviewing the manuscript.

\section{References}

1. Haase AT. Pathogenesis of lentivirus infections. Nature 1986; 322: 130-136

2. Mornex JF, Ecochard D, Greenland T, et al. Pneumopathies interstitielles diffuses dues aux lentivirus chez l'homme (HIV-1) et chez l'animal. Rev Mal Respir 1990; 7: 517-528.

3. White D, Matthay R. Noninfectious pulmonary complications of infection with the human immunodeficiency virus. Am Rev Respir Dis 1989; 140: 1763-1787.

4. Mornex JF, Lena P, Loire R, et al. Lentivirus-induced interstitial lung disease: pulmonary pathology in sheep naturally infected by the visna-maedi virus. Vet Res 1994; 25: 478-488.

5. Cordier G, Cozon G, Greenland T, et al. In vivo activation of alveolar macrophages in ovine lentivirus infection. Clin Immunol Immunopathol 1990; 55: 355-367.
6. Lairmore MD, Rosadio RH, Demartini JC. Ovine lentivirus lymphoid interstitial pneumonia: rapid induction in neonatal lambs. Am J Pathol 1986; 125: 173-181.

7. Cadoré JL, Guiguen F, Cordier G, et al. Early events in the experimental interstitial lung disease induced in sheep by the visna-maedi virus. Immunol Lett 1994; 39: 39-43.

8. Cordier G, Guiguen F, Cadoré JL, Cozon G, Jacquier MF, Mornex JF. Characterization of the lymphocytic alveolitis in visna-maedi virus-induced interstitial lung disease of sheep. Clin Exp Immunol 1992; 90: 18-24.

9. Lena P, Freyria AM, Lyon M, et al. Increased expression of tissue factor mRNA and procoagulant activity in ovine lentivirus-infected alveolar macrophages. Res Virol 1994; 145: 209-214.

10. Bast A, Haenen GRM, Doelman CJA. Oxidants and antioxidants: state of the art. Am J Med 1991; 91 (Suppl. 3C): 2S-13S.

11. Janssen YMW, VanHouten B, Borm PJA, Mossman BT. Cell and tissue responses to oxidative damage. Lab Invest 1993; 69: 261-274.

12. Heffner JE, Repine JE. Pulmonary strategies of antioxidant defense. Am Rev Respir Dis 1989; 140: 531-554.

13. Cross CE, van der Vliet A, O'Neill CA, Eiserich JP. Reactive oxygen species and the lung. Lancet 1994; 334: 930-933.

14. Lyon M, Huppert J. Depression of reverse activity by hybridoma supernatants: a potential problem in screening for retroviral contamination. Biochem Biophys Res Commun 1983; 112: 265-272.

15. Pick E, Keisari Y. A simple colorimetric method for the measurement of hydrogen peroxide production by cells in culture. J Immunol Methods 1980; 38: 161-170.

16. Lowry OH, Rosebrough NJ, Farr AL, Randall RJ. Protein measurement with the folin phenol reagent. J Biol Chem 1951; 193: 265-275.

17. Paglia DE, Valentine WN. Studies on the quantitative and qualitative characterization of erythrocyte glutathione peroxidase. J Lab Clin Med 1967; 70: 158-169.

18. Guillard O, Sonnet J, Lauwerys R. Reactive oxygen species production in whole blood from AIDS patients. Clin Chim Acta 1989; 185: 113-114.

19. Spear GT, Kessler HA, Rothberg L, Phair J, Landay A. Decreased oxidative burst activity of monocytes from asymptomatic HIV-infected individuals. Clin Immunol Immunopathol 1990; 54: 184-191.

20. Braun DP, Kessler H, Falk L, et al. Monocyte functional studies in asymptomatic, human immunodeficiency virus (HIV)-infected individuals. J Clin Immunol 1988; 8: 486-494.

21. Müller F, Rollag H, Froland SS. Reduced oxidative burst responses in monocytes and monocyte-derived macrophages from HIV-infected subjects. Clin Exp Immunol 1990; 82: 10-15.

22. Roux-Lombard P, Aladjem D, Balavoine JF, et al. Altered functions of peripheral blood monocytes in homosexual males and intravenous drug users with persistent generalized lymphadenopathy. Eur J Clin Invest 1986; 16: 262-270.

23. Nielsen H, Kharazmi A, Faber V. Blood monocyte and neutrophil functions in the acquired immune deficiency syndrome. Scand J immunol 1986; 24: 291-296.

24. Murray HW, Gellene RA, Libby DM, Rothermel CD, Rubin BY. Activation of tissue macrophages from AIDS patients: in vitro response of AIDS alveolar macrophages to lymphokines and interferon- $\gamma$. J Immunol 1985; 135; 2374-2377. 
25. Buhl R, Jaffe HA, Holroyd KF, et al. Activation of alveolar macrophages in asymptomatic HIV-infected individuals. J Immunol 1993; 150: 1019-1028.

26. Buhl R. Imbalance between oxidants and antioxidants in the lungs of HIV-seropositive individuals. Chem Biol Interact 1994; 91: 147-158.

27. Dukes CS, Matthews TJ, Weinberg JB. Human immunodeficiency virus type-1 infection of human monocytes and macrophages does not alter their ability to generate an oxidative burst. J Infect Dis 1993; 168: 459-462.

28. Sönnerborg A, Carlin G, Akerlund B, Jastrand C. Increased production of malondialdehyde in patients with HIV infection. Scand J Infect Dis 1988; 20: 287-290.

29. Revillard JP, Vincent CMA, Favier AE, Richard MJ, Zittoun M, Kazatchkine MD. Lipid peroxidation in human immunodeficiency virus infection. J AIDS 1992; 5: 637-638.

30. Eck HP, Gmünder H, Hartmann M, Petzoldt D, Daniel V, Dröge W. Low concentrations of acid-soluble thiol (cysteine) in the blood plasma of HIV-1 infected patients. Biol Chem Hoppe Seyler 1989; 370: 101-108.

31. Buhl R, Jaffe HA, Holroyd KJ, et al. Systemic glutathione deficiency in symptom-free HIV-seropositive individuals. Lancet 1989; ii: 1294-1298.

32. Staal FJT, Ela SW, Roederer M, Anderson MT, Herzenberg LA, Herzenberg LA. Glutathione deficiency and human immunodeficiency virus infection. Lancet 1992; 339: 909-912.

33. Legastelois I, Mornex JF, Cottin V, Cadoré JL, Cordier G. Interleukin-8 gene expression by sheep alveolar macrophages is increased after infection by the visna-maedi virus. Clin Res 1994; 42: 306A.

34. Israel N, Gougerot-Pocidalo MA, Aillet F, Virelizier JL. Redox status of cells influences constitutive or induced NF-карpa B translocation and HIV long terminal repeat activity in human $\mathrm{T}$ and monocytic cell lines. J Immunol 1992; 149: 3386-3393.

35. De Forge LE, Preston AM, Takeuchi E, Kenney J, Boxer LA,
Remick DG. Regulation of interleukin-8 gene expression by oxidant stress. J Biol Chem 1993; 268: 25568-25576.

36. Schreck R, Rieber P, Baeuerle PA. Reactive oxygen intermediates as apparently widely-used messengers in the activation of the NF- $\kappa \mathrm{B}$ transcription factor and HIV-1. EMBO J 1991; 10: 2247-2258.

37. Schreck R, Grassman R, Fleckenstein B, Baeuerle PA. Antioxidants selectively suppress activation of NF- $\kappa \mathrm{B}$ by human T-cell leukemia virus type-I Tax protein. $J$ Virol 1992; 66: 6288-6293.

38. Lenardo MJ, Baltimore D. NF-kappa B: a pleiotropic mediator of inducible and tissue-specific gene control. Cell 1989; 58: 227-229.

39. Mukaida N, Shiroo M, Matsushima K. Genomic structure of the human monocyte-derived neutrophil chemotactic factor IL-8. J Immunol 1989; 143: 1366-1371.

40. Mukaida N, Mahe Y, Matsushima K. Co-operative interaction of nuclear factor- $\kappa \mathrm{B}$ and cis-regulatory enhancer binding protein-like factor binding elements in activating the interleukin- 8 gene by proinflammatory cytokines. J Biol Chem 1990; 265: 21128-21133.

41. Legrand-Poels S, Vaira D, Pincemail J, van de Vorst A, Piette J. Activation of human immunodeficiency virus type-1 by oxidative stress. AIDS Res Hum Retrov 1990; 6: 1389-1397.

42. Kalebic T, Kinter A, Poli G, Anderson ME, Meister A, Fauci AS. Suppression of human immunodeficiency virus expression in chronically infected monocytic cells by glutathione, glutathione ester, and N-acetylcysteine. Proc Natl Acad Sci USA 1991; 88: 986-990.

43. Roederer M, Staal F, Raju PA, Ela SW, Herzenberg LA, Herzenberg LA. Cytokine-stimulated human immunodeficiency virus replication is inhibited by $\mathrm{N}$-acetyl-Lcysteine. Proc Natl Acad Sci USA 1990; 87: 4884-4888.

44. Ho Wz, Douglas SD. Glutathione and N-acetylcysteine suppression of human immunodeficiency virus replication in human monocyte/macrophages in vitro. AIDS Res Hum Retrov 1992; 8: 1249-1253. 